\title{
Research on the Demand of Community Home-stay Pension Service by the Elderly in Beijing
}

\author{
$\mathrm{Na} \mathrm{Yu}^{1,2}$ \\ ${ }^{1}$ School of Management and Economics \\ Beijing Institute of Technology \\ Beijing, China \\ yuna@bjmu.edu.cn
}

\author{
${ }^{2}$ Peking University Medical Informatics Center \\ Peking University \\ Beijing, China \\ yuna@bjmu.edu.cn
}

\begin{abstract}
To ease the deteriorating issue of ageing and to satisfy the daily pension demand of the elderly, the community home-stay pension service is being promoted in Beijing. In order to improve the community home-stay service and understand the demands of the service in details by the elderly, an analysis has been done in the difference of demands by the elderly in the community home-stay pension service, based on the questionnaire conducted in 9 communities in Beijing, from the aspects of price of hourly maid worker, to-door service, regular health checkup, to-door diagnosis and to-door care.
\end{abstract}

Keywords: home-stay pension service, pension service demand, to-door service

\section{INTRODUCTION}

Effective from 1st of January, 2010. the Approach for Beijing Citizen Home-stay Pension Service (including Help to the Handicapped) was jointly issued by the Civil Affairs Bureau in Beijing together with another 13 government departments. In this Approach, all communities were specifically requested to establish the rules of pension service ticket, set up canteens for the elderly and build the community old folks' home. And the old folks' home shall be built in each and every community or village in Beijing within 3 years[1].

To carry out professional and personalized community home pension service, we will have to find out the demand in to-door service by the elderly. Hereinafter, we will discuss it from the aspects of price of hourly maid worker, to-door service, regular health checkup, to-door diagnosis and todoor care[2].

\section{METHOD}

Wherever Times is specified, Times Roman or Times New Roman may be used. If neither is available on your word processor, please use the font closest in appearance to Times. Avoid using bit-mapped fonts if possible. True-Type 1 or Open Type fonts are preferred. Please embed symbol fonts, as well, for math, etc.

\section{A. Research objects}

This research distributed 986 questionnaires to the elderly who are 60 years old and above, and collected 986 valid questionnaires. Among the 986 elderly, 36\% (355) are male and the balance is female. The interviewees are from 60-years-old to 94-years-old. Most are from 60-years-old to 80 -years-old, and the interviewees above 80 are minimal. $34 \%$ of the interviewees are senior high school graduates; $28 \%$ has junior high school education, $15 \%$ has primary or lower education, very few have master degrees or above; $22 \%$ graduated from university or specialists. The main source of income of the $96.5 \%$ is their own retirement salary, $1.2 \%$ receives alimony, $3 \%$ have savings and investment income, few receive government grants or other sources of income. Approximately $36 \%$ of the surveyed said their monthly income was between 1,000 to 2,000 Yuan, nearly $50 \%$ is between 2000-4000 Yuan, few are lower than 1000 Yuan or higher than 4000 Yuan.

\section{B. Research Methods}

The questionnaire contains: basic personal information, pension will and pension services, financial security in the status quo, life care status and demands, health care status and demands, solace and legal protection status and demands, volunteer service.

\section{RESULT}

\section{A. Analysis in the Price of hourly maid worker}

On the wish list of services to be carried out by the community, the low-income elderly have high demands on various services, in particular the pension services provided by the community stations and volunteers. Their spending on the expensive pension service is quite limited due to their financial conditions[3].

\begin{tabular}{|c|c|c|c|c|c|c|}
\hline $\begin{array}{c}\text { Monthly } \\
\text { Income }\end{array}$ & $\begin{array}{l}\text { Belo } \\
\text { w } \\
\text { RMB } \\
10 \\
\end{array}$ & $\begin{array}{l}\text { RMB } \\
10-15\end{array}$ & $\begin{array}{l}\text { RMB1 } \\
6-20\end{array}$ & $\begin{array}{l}\text { Above } \\
\text { RMB20 }\end{array}$ & $\begin{array}{l}\text { Not } \\
\text { Conside } \\
\mathbf{r}\end{array}$ & $\begin{array}{l}\text { Not } \\
\text { require }\end{array}$ \\
\hline $\begin{array}{l}\text { Below } \\
\text { RMB1000 }\end{array}$ & 83.6 & 7.3 & 0.0 & 0.0 & 7.3 & 1.8 \\
\hline $\begin{array}{l}\text { RMB1000- } \\
2000\end{array}$ & 78.3 & 12.9 & 3.5 & 0.9 & 2.9 & 1.5 \\
\hline $\begin{array}{l}\text { RMB2000- } \\
4000\end{array}$ & 63.0 & 21.3 & 5.0 & 3.6 & 3.9 & 2.9 \\
\hline $\begin{array}{l}\text { Above } \\
\text { RMB4000 }\end{array}$ & 45.4 & 23.7 & 21.6 & 2.1 & 1.0 & 6.2 \\
\hline $\begin{array}{l}\text { Grand } \\
\text { Total }\end{array}$ & 68.0 & 17.7 & 5.9 & 2.2 & 3.4 & 2.7 \\
\hline
\end{tabular}


Another obvious finding is that the low-income elderly are only willing to accept the lowest price by the hourly maid workers, while the high-income elderly are willing to pay the hourly maid workers as per the market price. So we shall consider the affordability of the elderly[4] and provide different types of service at different price, for them to choose.

\section{B. Analysis on the Demand of To-door Care Service}

As becoming old year by year and the declining of the self-care capability, the demands of pension services from the elderly is increasing tremendously. And the same result in the to-door care service, community station service and volunteer service.

TABLE II. THE DEMAND OF TO-DOOR CARE SERVICE BY THE ELDERLy OF DifFERENT AGES [N(\%)]

\begin{tabular}{cccc}
\hline Ages & Yes & No & Total \\
\hline 60-70 YO & $305(51.6)$ & $286(48.4)$ & $591(100)$ \\
70-80 YO & $150(52.1)$ & $138(47.9)$ & $288(100)$ \\
Above 80 YO & $68(70.1)$ & $29(29.9)$ & $97(100)$ \\
Grand Total & $523(53.6)$ & $453(46.4)$ & $976(100)$ \\
\hline
\end{tabular}

\section{Analysis on the Demand of Regular Health Checkup}

Most of the elderly have difficulty in walking and they have very high expectations in the to-door care services by the community health stations. As showing in Table 2, most of the elderly above 80 years old wish the community health stations could provide the to-door care service, as well as todoor diagnosis and health guidance, with the result of $\mathrm{x} 2=11.832$ and $\mathrm{P}=0.003<0.05$. There is no big difference in demand of the services to be done at the station like the periodical medical checkup, between the elderly of different ages, with the result of $\mathrm{x} 2=0.449$ and $\mathrm{P}=0.799$. This reminds us to consider the walking difficulties of the elderly when providing the pension service, especially the medical service.

TABLE III. ThE DEMAND OF REgUlar MEDICAL CHECKup By THE ELDERLY OF DIFFERENT AGES [N(\%)]

\begin{tabular}{cccc}
\hline Ages & Yes & No & Total \\
\hline 60-70 YO & $392(66.3)$ & $199(33.7)$ & $591(100)$ \\
& $196(68.1)$ & $92(31.9)$ & $288(100)$ \\
70-80 YO & $67(69.1)$ & $30(30.9)$ & $97(100)$ \\
Gbove 80 YO & $655(67.1)$ & $321(32.9)$ & $976(100)$ \\
\hline
\end{tabular}

D. Analysis on the Demand of To-door Diagnosis

TABLE IV. THE DEMAND OF TO-DOOR DiAgNOSIS BY THE ELDERLY OF DifFERENT HEALTH STATUS [N(\%)]

\begin{tabular}{lccc}
\hline Health Status & Yes & No & Total \\
\hline Excellent & $77(45.1)$ & $90(53.9)$ & $167(100)$ \\
Good & $275(46.9)$ & $265(49.1)$ & $540(100)$ \\
Average & $91(47.4)$ & $101(52.6)$ & $192(100)$ \\
Bad & $47(68.1)$ & $22(31.9)$ & $69(100)$ \\
Very Bad & $8(100)$ & $0(0)$ & $8(100)$ \\
Grand Total & 498 & 478 & $976(100)$ \\
\hline
\end{tabular}

The different in the health status is reflected more in the demand of the medical service. As what shows in Table 4, the elderly who think they are not healthy enough have more demands in the to-door diagnosis from the community health station, with the result of $\mathrm{x}^{2=} 18.374$ and $\mathrm{P}=0.001$. It is also true in the demand of to-door care service, as shown on Table 5 with the result of $\mathrm{x}^{2=} 22.481$ and $\mathrm{P}=0.000$.

TABLE V. The Demand OF To-DOor Care SERVICE By The ELDERLY OF DifFERENT HEALTH STATUS [N(\%)]

\begin{tabular}{lccc}
\hline Health Status & Yes & No & Total \\
\hline Excellent & $78(46.4)$ & $90(53.6)$ & $168(100)$ \\
Good & $276(51.1)$ & $264(48.9)$ & $540(100)$ \\
Average & $114(59.1)$ & $79(40.9)$ & $193(100)$ \\
Bad & $49(71.0)$ & $20(29.0)$ & $69(100)$ \\
Very Bad & $8(100)$ & $0(0)$ & $8(100)$ \\
Grand Total & 525 & 453 & $978(100)$ \\
\hline
\end{tabular}

\section{CONCLUSION}

On one hand, the low-income people welcome the lowprice or even free pension services provided by the community. On the other hand, the high-income people who are normally more knowledgeable and experienced, are more likely to opt for the quality service at a higher price[5]. The low-income elderly have a higher requirement on the various life-care services provided by the community, especially in the community station service and volunteer service. Their expenditure on the expensive pension service is limited by the economical burden. So we shall consider the affordability of the elderly and provide different types of service at different price, for them to choose[6].

As becoming old year by year and the declining of the self-care capability, the demand of to-door care services from the elderly is increasing tremendously. Most of the elderly have difficulty in walking and they have very high expectations in the to-door services, nearby health checkup, to-door diagnosis, and to-door care provided by the community. Like most of the elderly above 80 years old, the elderly with bad health status require more to-door medical service.

\section{REFERENCES}

[1] Documents of China National Working Committee on Ageing and National Development and Reform Commission etc, forwarded by the General Office of the State Council of the People's Republic of China: "Notice on Quickening the Development of the Pension Service" (GOSC-2006-6)

[2] Lao Yinqian,Cao Weigu,Li Yingdan, "How the Medical Insurance System to Face the Impact of the Ageing Society,"A Review of Labor Unions: Theory and Reserch,Beijing, vol.7, 2011, pp. 133-134.

[3] Kathleen Melnnis-Dittfich,Sui Yujie, “The Evaluation and Intervention of Physiology, Psychology and Social Aspect in Ageing Society Work,” China Renmin University Press,Beijing, 2008, page 91.

[4] Pei Xiaomei, Fang Lijie, "Introduction of Long-term Care for the Elderly,” Social Science Academic Press, Beijing, 2010, pp. 48-49.

[5] Dong Yahong, "The Analysis and Reform of the Social Pension Service System in China,” Social Science, Beijing, vol.3, 2012, pp. 68-75. 
[6] Zhuang Qi, “ The Current Status and Solution for the Urban Community Home Pension Service in China”, Journal of Beijing
Vocational College of Labor and Social Security, Beijing, vol.4, 2008. 